\title{
The Participation of Lampulo Community in Marine Conservation Management Efforts at Fish Auction Place Lampulo Area, Banda Aceh City
}

\author{
Furqan $^{1}$, Yuli Khairani ${ }^{2}$, Erdi Surya ${ }^{3 *}$ M. Ridhwan $^{4}$, Armi $^{5,}$ Anita \\ Noviyanti $^{6}$, Muchsin ${ }^{7}$ Yeni Rimadeni ${ }^{8}$ \\ ${ }^{1,2}$ Islamic Communication and Broadcasting, Faculty of Tarbiyah, Universitas \\ Serambi Mekkah. Banda Aceh, 23245, Indonesia \\ ${ }^{3,4,5,6}$ Department of Biology Education, Faculty of Teacher Training and Education, \\ Universitas Serambi Mekkah, Banda Aceh, 23245, Indonesia \\ ${ }^{7}$ English Department,Faculty of Teacher Training and Education, Universitas \\ Serambi Mekkah. Banda Aceh, 23245, Indonesia \\ ${ }^{8}$ Nursing Health Department, Poltekkes Aceh. Aceh Besar, 23352, Indonesia \\ *Corresponding Author: Erdi Surya, suryaerdi14@yahoo.com
}

\begin{abstract}
This study has been conducted with the participation of Lampulo Community inmarine conservation efforts at the Fish Auction Place of Lampulo area, Banda Aceh. The population in this study was the entire fishing communityat Fish Caution Place in Lampulo area. Whereas, the samples in this study were 20 people including 16 people of fishing community, one boat commander-in-chief, one village chief, one village secretary, and one sea commander. The instruments in this research were interviews and questionnaires. Data collected through interviews and questionnaires showed that the level of participation by communities in marine conservation efforts wasin good categories and the management without any existing rules, written or unwritten rules. They utilized the mangrove forest to avoid cut down.Fishing was prohibited from using toxins that could harm marine ecosystems. Frequently, community-related to Lampulo area was held on a large scale to preserve the resources of the fishing community. Counseling about the importance to keep the conservation of the oceans at bay was often carried out. Fishermen also looked forward to both tooling and infrastructure in the management of marine conservation so that the sea will be kept in good conditions.
\end{abstract}

Keywords: participation, management, ocean, conservation.

\section{Introduction}

Participation is the action of taking part in an activity or event that gives thinking to something or someone. It is also the contribution of communities in development programs. Participation can be differentiated into spatial and mobility. Spatial participation implies that participation is based on awareness and self-determination, while the participation of mobilization has the sense of having a contribution based on the other influences. Furthermore, Anggoro (2006) divided the participants into several stages. The decision-making (planning) stages have been manifested by the close participation of societies. The stage of execution with visible participation: in the comprehended form, material contributions form, and in engagement form of project.The stage of enjoying in the results can be an indicator achievement of community participation in the planning and implementation of the project. In addition, it had been given the people position as the development subject, more benefits of the project are successfully undertaken. The evaluation stageis deemed important because of community participation.

Darmawan (2007) allocatedthe community participation into: 1) community control, power is delegated to society to make decisions and inform the government; 2) partnership, governments, and peoples together in decision making; 3 ) advisory, society offers guidance 
to governments in making decisions, but decisions are entirely government, 4) communicative, two-way information exchange, local attention is represented in management planning; 5) cooperative, a community including the management (power); 6) consultative, a mechanism by which governments consult fishermen, but the entire decision is made by researchers, and informative, the public is informed that the government's decision is complete.

Based on interviews and observations of the people at a Fish Auction Place in Lampulo area, fishermen both behaved and became were the first to feel the effects of damaging the environment at this place, since overharvesting and exploiting the natural resources. Public participation was particularly noteworthy in ocean conservation management activities. Communities accepted this concept adapted to coastal and marine ecosystems through the goal of preventing overexploitation, biodiversity conservation, and habitat protection in ocean conservation areas.

As management becomes more integrated and comprehensive, the marine conservation area becomes more important tool for the conservation of sea resources. Marine conservation areas have been suggested as integrated components, building a network of marine conservation areas intended at improving coastal and marine management (Done and Reichelt, 1998). Nevertheless, the implementation is hampered by a lack of understanding of how to design ocean conservation areas to maximize their function. The local fishermen's behavior as local wisdom in preserving the environment is projected in ways consistent through local assumption and tradition. They are expected to bring about concepts and ways to maintain the preserving the ecological balance.

Local wisdom in a community is usually guarded by a local elder or local figure, a way of preserving local wisdom can be taught to the younger generation. Teaching could be programmed or written as well as incidental activity in a society. By safeguarding and continuing the local communities, it is expected that they will not fade or disappear but carry on to live in communities and to exist for a balanced environment. It is further explained that prudence reflects quality decisions. The measure of a worthwhile decision is that of a character/a number of persons by tracing problems that develop and understanding them. Then a decision was made in such a way that associated, it would seek to implement it in the range of those who rejected the decision until those who agreed with it (Dahuri, et al., 2009).

According to the last law, more concrete was confirmed in the 2008 Qanun Aceh No. 10 about the traditional development and a way of life. In part 10 of the text (1) letter (f), it is explained that the cultivation and development of local life and customs can be done with "protection of the local people rights, including land, swamps, forests, seas, rivers, lakes and other communities." The management of marine and coastal resources is also included in this specification.

Based on the description, we interested in researching the participation of the fishing community in ocean conservation efforts at the Fish Auction Place in Lampulo area, Banda Aceh. This study wasperformed to find out how Lampulo community manages the conservation at the Fish Auction Place in Lampulo area and their participation in marine conservation management efforts.

\section{Method}

The research was conducted at the Fish Auction Place of Lampulo area, Banda Aceh city. The study wasa qualitative descriptive that is nonexperimental research. The descriptive study is a study that attempts to interpret objects in authenticity (Best in Darmadi, 2011). The populations in this study were all fishermen at Fish Auction Place of Lampulo area as well as village bureaucrat and sea influential. While the samples in this 
study were 20 people: 16 people of fishing communities, one boat commander-in-chief, one village chief, one village secretary, and one sea commander. The instruments in this research were interviews and questionnaires.

The process of analyzing the data using qualitative descriptive analyzes which describes a phenomenon based on observations and interviews. A descriptive study that describes or describes existing and natural phenomena without anecdote (Arikunto, 2002).Interviews could be done to find out the information directly by asking questions among the interviewer and the interview. The interview can be used to push identity. Questionnaires were used to pass a few questions on a research subject to get a written response. Questionnaires were used to find out the fishermen's perceptions ata Fish Auction place of Lampulo, as well as to the community part and local leaders. To analyze the researcher's number of using the following percentage formulas:

$$
P=\frac{f}{n} \times 100 \%(\text { Sudjana, 2005): }
$$

Where:

$\mathrm{P}=$ percentage

$\mathrm{F}=$ respondents (frequency)

$\mathrm{N}=$ sample number

$100 \%$ constant numbers

Interpretation criteria as follows:

$\begin{array}{ll}100 \% & \text { the whole thing } \\ 80-99 \% & \text { in general } \\ 60-79 \% & \text { the majority } \\ 50-59 \% & \text { over half } \\ 40-49 \% & \text { less than half } \\ 20-39 \% & \text { a fraction } \\ 0-19 \% \text { very little }\end{array}$

\section{Results}

The results of this study were divided into two parts: questionnaires and the results of interview. Researchers observed and interviewed for more specific information about the data. People's perceptions about the management of the conservation area can be seen in Table 1.Table1 indicates that as many as 15 people $(75 \%)$ or more than half the respondents responded very good to marine conservation, 3 people (15\%) answered good, 2 people $(10 \%)$ answered poor. It could be concluded that more than half the respondents knew very well about ocean conservation.

Table 1. The Respondents's Knowledge of Conservation Understanding.

\begin{tabular}{|c|c|c|c|}
\hline No & Alternative Answers & Frequency & Percentage (\%) \\
\hline 1 & Very good & 15 & $75 \%$ \\
\hline 2 & Good & 3 & $15 \%$ \\
\hline 3 & Poor & 2 & $10 \%$ \\
\hline 4 & Very poor & 0 & $0 \%$ \\
\hline & Total & 20 & $100 \%$ \\
\hline
\end{tabular}

For question No. 2, the result can be seen in Table 2.Table 2 shows that 13 people (65\%) responded to the environmental conditionsat Fish Auction Place that were currently affected by current respondentswere very good. There were 7 people $(35 \%)$ who responded with good category, and no one answered with very bad category. The above respondents' answers can be concluded that most of the respondents responded to the environmental conditions were very good. 
Table 2. Environmental Conditions at Fish Auction Place in LampuloArea.

\begin{tabular}{clcc}
\hline No & Alternative Answers & Frequency & Percentage (\%) \\
\hline 1 & Very good & 13 & $65 \%$ \\
2 & Good & 7 & $35 \%$ \\
3 & Bad & 0 & $0 \%$ \\
4 & Very bad & 0 & $0 \%$ \\
& & $\mathbf{2 0}$ & $\mathbf{1 0 0 \%}$ \\
\hline
\end{tabular}

Table 3 exhibits the answer of question No. 3.Table3 shows that 10 people $(50 \%)$ answered very necessary to protect coral reefs because they are one of the ecosystem' supports. There were 7 people $(35 \%)$ who answered it necessary to protect coral reefs. 2 people (10\%) answered less necessary and 1 person $(5 \%)$ answered unnecessary to protect coral reefs. Based on the above answers, the most majority of the respondents responded to protecting coral reefs with very necessary.

Table 3. The respondents feel whether the reef is protected or not.

\begin{tabular}{clcc}
\hline No & Alternative Answers & Frequency & Percentage (\%) \\
\hline 1 & Very necessary & 10 & $50 \%$ \\
2 & Necessary & 7 & $35 \%$ \\
3 & Less necessary & 2 & $10 \%$ \\
4 & Unnecessary & 1 & $5 \%$ \\
& Total & $\mathbf{2 0}$ & $\mathbf{1 0 0 \%}$ \\
\hline
\end{tabular}

The respond for question No.4 can be seen in Table 4.Table 4 shows that 15 people (75\%) fishermen knew very good about ocean conservation, there were 3 people $(15 \%)$ answered"good", 2 people (10\%) answered"bad" and no one answered "very bad". From the responds, there was a great deal about ocean conservation.

Table 4. Knowledge of ocean conservation.

\begin{tabular}{clcc}
\hline No & Alternative Answers & Frequency & Percentage (\%) \\
\hline 1 & Very good & 15 & $75 \%$ \\
2 & Good & 3 & $15 \%$ \\
3 & Bad & 2 & $10 \%$ \\
4 & Very bad & 0 & $0 \%$ \\
& & $\mathbf{2 0}$ & $\mathbf{1 0 0 \%}$ \\
\hline
\end{tabular}

Table 5 presents the answer of question No. 5.Table 5 shows that 15 people $(75 \%)$ answered very capable in marine protected areas for fishermen especially fishermen in Fish Auction Place of Lampulo or local fishermen, there were 5 (25\%) responded capably. No one answered incapable. It was generally deferred that the respondents answered that a very capable protection area for fishermen was served.

Table 5. Sea Protection Areas Serve Fishermen ALot of Good.

\begin{tabular}{|c|c|c|c|}
\hline No & Alternative Answers & Frequency & Percentage (\%) \\
\hline 1 & Very capable & 15 & $75 \%$ \\
\hline 2 & Capable & 5 & $25 \%$ \\
\hline 3 & Less capable & 0 & $0 \%$ \\
\hline 4 & Incapable & 0 & $0 \%$ \\
\hline & Total & 20 & $100 \%$ \\
\hline
\end{tabular}

Table 6 presents the respond for question No. 6. Based on Table6, it shows that 20 people $(100 \%)$ who responded "strongly agree" of the benefits of marine protection to the fishing community in increasing the fish population.All respondents were strongly agreed with the benefit of marine protection to fishermenin the Fish Auction Place of Lampulo. 
Table 6. Examples of the Benefits of Marine Protection to Fishermen.

\begin{tabular}{clcc}
\hline No & \multicolumn{1}{c}{ Alternative Answers } & Frequency & Percentage (\%) \\
\hline 1 & Strongly agree & 20 & $100 \%$ \\
2 & Agree & 0 & $0 \%$ \\
3 & Less agree & 0 & $0 \%$ \\
4 & Disagree & 0 & $0 \%$ \\
& & $\mathbf{2 0}$ & $\mathbf{1 0 0 \%}$ \\
\hline
\end{tabular}

Table 7 shows the responds for problem No. 7.Table 7 shows that 17 people (85\%) responded strongly agree when fishing communities who harm the marine conservation environment in the case of coral reefs must be punished. There were 3 people $(15 \%)$ who said agree. Based on the results, it could be concluded that it was generally strongly agree for the offending one to be punished according to the rules.

Table 7. For the responders that harm coral reefs should be punished.

\begin{tabular}{|c|c|c|c|}
\hline No & Alternative Answers & Frequency & Percentage (\%) \\
\hline 1 & Strongly agree & 17 & $85 \%$ \\
\hline 2 & Agree & 3 & $15 \%$ \\
\hline 3 & Less agree & 0 & $0 \%$ \\
\hline 4 & Disagree & 0 & $0 \%$ \\
\hline
\end{tabular}

Table 8 shows the answer for problem No.8. Table 8 presents that 17 people $(85 \%)$ answered absolutely should be a rule about ocean conservation, as rules are a guide for fishermen in their sea activities, there were 3 people answers should be, and $0 \%$ answer less should be and should not be. From the result, it can be concluded that there must generally be strictrules applied to fishermen so that fishermen can understand and can carry out the rules.

Table 8. Should Be Rules for Ocean Conservation?

\begin{tabular}{clcc}
\hline No & Alternative Answers & Frequency & Percentage (\%) \\
\hline 1 & Absolutely should be & 17 & $85 \%$ \\
2 & Should be & 3 & $15 \%$ \\
3 & Less should be & 0 & $0 \%$ \\
4 & Should not be & 0 & $0 \%$ \\
& Total & $\mathbf{2 0}$ & $\mathbf{1 0 0 \%}$ \\
\hline
\end{tabular}

To answer question No. 9, Table 9 was provided.Based on Table 9, a penalty was prescribed for fishermen in violation of the terms set by the sea captain. It can be concluded that all of the respondents answered that there must be a penalty given for breaking the rules.

Table 9. Penalties given to fishermen for breaking the rules.

\begin{tabular}{clcc}
\hline No & \multicolumn{1}{c}{ Alternative Answers } & Frequency & Percentage (\%) \\
\hline 1 & Absolutely should be & 20 & $100 \%$ \\
2 & Should be & 0 & $0 \%$ \\
3 & Less should be & 0 & $0 \%$ \\
4 & Should not be & 0 & $0 \%$ \\
& Total & $\mathbf{2 0}$ & $\mathbf{1 0 0 \%}$ \\
\hline
\end{tabular}

Based on interviews with fishermen regarding the management of marine conservation, it is known that sea conservation is a real expression of some act of coastal resources management to maintain the biodiversity that is closely related to ecosystems that are ocean biodiversity. So that, an environment in particular the marine neighborhood can be sustained, allowing coastal resources to be used continuously. 
In addition to the environmental issues occurring in coastal areas of fish Auction place, Lampulo such as the taking of coral reefs, environmental pollution, and even environmentally poor fishing require restoration measures and prevention to prevent the directly or indirectly declining production of fisheries and to protect the resources fisheries optimally sustainably.

Furthermore, the communities of fishermen and sea leaders are also said to be very well-informed about the preservation areas. Because the preservation area is a staging area, conservation, and utilization area for conservation. Fishermen provide a model of protection like being banned from cutting down mangroves, throwing out the garbage in the seas, and damaging the marine ecosystems' habitats. If there isn't doing activity based on rules, it will give a penalty such as warning, administrative, and a ban on seas as policy.

\section{Discussion}

Data analysis suggests that the majority of fishermen already know about conservation. Because it is conservation, maintenance, utilization, sustainability, restoration, and improvement of natural environments. According to Bengen (2002), it has been suggested that for ecosystems and resources to play optimally and sustainably, protection efforts from degraded threats are needed either directly or indirectly. An area is urgently needed to be managed so that biodiversity and marine conservation resources can be cared for and maintained for the prosperity of the people especially the fishing community. Because coastal fishing communities are one factor in environmental management.

The result of interviews with fishermen for marine protection in Fish Auction Place of Lampulo was to increase the fish population, so if any communities damaged the natural environment especially the reefs, sanctions would have to be given. As in the traditional penalties that despoiled fishermen were all captured and forbidden to go to sea for 3-7 days.

The results of this study coincided with those of earlier studies, such as Witanto (2011), suggested that specific forms of violation of the sea law have several types of penalties that could be applied to customers like mandatory, social gatherings, sailing is forbidden for a while, fishing catch, penalties, despoliations of trawlers. According to Sulaiman (2013), a law sanction for breaking was that all those captured would be seized and banned since seas for 7 days.

Interview reports show that the reef activity has been carried out over the years, and thus the reefs are kept in check from the dangers of marine ecosystems. When coral reefs are not well guarded, they can result in loss of the function of improved beach erosion and other coastal damages. It may also pose a major threat to the sustainability of fisheries and coral reef ecosystems. In many ways, communities of fishermen have been able to keep the reef awake, especially when the reef is destroyed with explosives and excavation. The coral reef is not only a wonderful tourist attraction but also a source of life. Dahuri (2002) suggested that the potential coastal resources were generally subtracted into four such groups asthe resurgent resources between fish, shrimps, seaweed, and others; the ocean's energy cleats, waves, and others; and marine environmental services include tourism and marine migration.

The interviews also showed that people were involved in maintaining sea conservation by never throwing garbage into the sea, cutting down mangroves around the area of Lampulo beach. Continually to keep the plants around the beaches planted to grow properly. Arifin (2003) suggested that the reduced area of mangrove forests has an impact on the disruption of the coastal area due to waves.

\section{Conclusions}

The conclusion can be made that the participation of fishing communities in terms of ocean conservation was very good, where fishing communities played an active role in maintaining coral reefs, never throwed garbage into the seas, always followed the rules 
made by sea captains and relevant parties. Among other things, sharing in the suggestions and proposals for future activities has been to keep the coastal area of Lampulo from taking fish in ways that damage marine ecosystems.

\section{References}

Arifin Arief. (2003).Hutan Mangrove Fungsi dan Manfaatnya(The mangrove forests are its functions and benefits). Yogyakarta: Kansius.

Arikunto. (2002). Prosedur Penelitian (research procedure), Jakarta: Rineka Cipta

Anggoro. (2006). Modul Matrikulasi Pengelolaan Pesisir dan Lautan Berwawasan Lingkungan (The matrikulation module for coastal and ocean-oriented management). Seminar Nasional Fakultas Teknik dalam Rangka Dies Natalis. Semarang: Universitas Diponegoro.

Bengen. (2002). Ekosistem dan Sumberdaya Alam Pesisr dan Laut Serta Prinsip Pengelolaannya (Ecosystems and Marine resources and principles their governing). Bogor: IPB.

Dahuri. (2002). Keanekaragaman Hayati Laut Ases Pembangunan Berkelanjutan Indonesia (Biodiversity of the sea ases sustainable development of Indonesia). Jakarta: Gramedia Pustaka Utama.

Darmadi, H. (2011). Metode Penelitian Pendidikan (Educational research methods). Bandung: Alfabeta.

Darmawan, Agus. (2007). Kajian Kebijakan Pengelolaan Kawasan Konservasi Laut yang Menunjang Perikanan Berkelanjutan pada Era Otonomi Daerah (Kasus Taman Nasional Bunaken dan Daerah Perlindungan Laut),(A study of policy management of Marine conservation areas that promotes sustainable fishing in an era of autonomy (cases of the bunaken national park and Marine protection). Tesis: Program Pasca Sarjana IPB.

Dahuri, dkk. (2009). Keanekaragaman Hayati Laut (Marine biodiversity).Jakarta: PT. Gramedia.

Done, T.J., and R.E. Riechelt. (1998). Integrated Coastal Zone and Fisheries Ecosystem Management: Generic Goals and Performance Indices. Ecological Applications, 8(1), 110-118.

Satria. (2002). Pengelolaan Sumberdaya Wilayah Pesisir dan Lautan Secara Terpadu (Coastal and ocean-resource management in one).Jakarta: PT. Pradnya Paramita.

Khomsah. (2012). Pengelolaan Sumber daya Pesisir(Coastal resources management). Surakarta: YumaPustaka.

Qanun Aceh Nomor 10 Tahun 2008 Tentang Lembaga Adat (about the customs institute)

Sudjana. (2005). Penelitian dan Penilaian Pendidikan (Research and education assessment). Bandung: Sinar Baru Bandung

Tjokroamindjoyo, B. (1990). Perencanaan Pembangunan(Planning the development). Jakarta: C.V. Mas Agung.

UU Nomor 11 Tahun 2006 Tentang Pemerintahan Aceh.(Rules of aceh).

Undang-Undang Republik Indonesia Nomor 45 Tahun 2009 Tentang Perikanan (on fisheries).

Sulaiman. (2013). Prospek Hukum Adat Laut dalam Pengelolaan Perikanan di Kabupaten Pidie Jaya Provinsi Aceh (The prospect for ocean customs law under fisheries management in Pidie jaya province Aceh). Yustisia. 2(3), 15-22.

Witanto, D.Y. (2011). Metode Penyelesaian Konflik dalam Dimensi Kearifan Lokal Masyarakat Pesisir Pantai Sabang (Perpektif dalam Sudut Pandang Sosio Cultural (Online), (Conflict resolution methods in local coastal civilisations of sabang (perpekt in a socio cultural (online). http://hkmperadilan.blogspot.co.id/2011/02/normal-0-false-false-false5016.html. 